\title{
]2[
}

\section{The Iphigenia in Aulis}

The voluntary sacrifice of young people to save family or city or nation in a situation of social crisis (usually war) is a common theme in Euripides. ${ }^{1}$ Besides Iphigenia in the Iphigenia in Aulis, other examples are Polyxena in the Hecuba, Macaria in the Heracleidae, Menoeceus in the Phoenissae, and, in the lost plays, the daughter (ultimately daughters) of Erechtheus and Praxithea in the Erechtheus and Phrixus in the Phrixus. These voluntary sacrificial deaths share several features. The victim is always a virgin, usually a young woman. The sacrifice is made as an act of piety in response to a supernatural command or pronouncement voiced by an oracle, prophet, or ghost. Generally the kin of the victim attempt to dissuade the young person from obeying the supernatural

A shorter and somewhat different version of this chapter was published as Foley I $982 \mathrm{~b}$.

'On voluntary sacrificial action in Euripides, see Schmitt I92 I, Roussel I922, Strohm 1957: 50-63, Burnett I97I: 22-26, and Vellacott 1975: i78-204. I refer here exclusively to voluntary sacrificial actions that involve the ritual slaying of virgins in times of social crisis, and not to the voluntary acceptance of death or suicide by adults, as in the case of Megara in the Heracles, Evadne in the Suppliants, or Pylades in the IT. Human sacrifice at times of social crisis was threatened and reported actually to have occurred at rare moments in Greek history. On this question, including a discussion of the Iphigenia myth, see Henrichs I98I. Accordingly, the voluntary sacrifices of tragedy must be understood as primarily fictional, an opportunity for the victims to express an active choice for arete and eukleia despite the resistance of their near relations (on these aspects of voluntary sacrifice, see especially Strohm). On animal sacrifices bef ore battle, see the discussion of Pritchett I97I: I09-I I5 and I979: 83-90 with further bibliography. 


\section{Ritual Irony}

command, thereby sharpening for the audience the conflict between the interests of family and city. Frequently, the assertion of the victim's determination to die is followed by farewells, departure, and a messenger's account of the heroic death. In each case, however, the dramatic context in which the sacrifice occurs creates special problems for the interpretation of this ultimate act of heroic resignation and/or piety and devotion to family or community. The focus on the innocent victim intensifies sympathy for his or her noble death, but the cause for which the victim dies is frequently dubious and the consequences of the ritual death are of ten ambiguous.

In the Iphigenia in Aulis, performed posthumously with his Alcmaion and Bacchae in 405, Euripides expands the motif of the voluntary sacrifice of an innocent youth to form the basis for and climax of an entire dramatic action. This expansion of the motif is only one of the apparently unique features of the voluntary sacrificial action in the play. Iphigenia dies not to save a threatened city or family, but for a Panhellenic war that has not yet begun and apparently does not have to be undertaken. In Calchas' prophecy Artemis demands the sacrifice of Iphigenia only if the expedition is to be undertaken. The sacrifice closes the play and clearly achieves its purpose: the Greek army can now depart for Troy. The plot develops without any obvious divine interference, and Iphigenia's heroic decision returns the myth to its traditional course and thus serves the function of the typical deus ex machina. ${ }^{2}$ Yet the text makes clear that the cause for which the sacrifice is made, Helen and the Trojan war, is a dubious one. It is uncertain whether the play closed with the substitution of a deer for Iphigenia and an apparent translation of the girl to divine status, reported by a messenger; with the appearance of Artemis on the machine to make a similar point; or only with Iphigenia's assertion that she should not be mourned in the fashion traditional to other such sacrificial victims. In all three cases the play affirms a divine status for its heroine markedly different from her known predecessors. ${ }^{3}$

2For a recent discussion of Iphigenia's role as a deus ex machina, see Schreiber I 963: 57-60. See Chapter 3 on Menoeceus' similar role.

${ }^{3} \mathrm{~A}$ fragment of Euripides' Erechtheus promises divine honors to the king's sacrificed daughter and her sisters, but this promise occurs af ter their deaths, whereas 
The major difficulty for interpreters of the play is how to evaluate Iphigenia's final idealistic conversion to self-sacrifice. ${ }^{4}$ On the one hand are the dubious cause for which the war is fought and the rhetoric and tone of the action before the final scenes: the everincreasing lust (erōs) for violence (eris) in the Greek army, the vacillations and self-serving motives of Agamemnon and Menelaus as leaders of the expedition, the pomposity of the future war hero Achilles, and the fiercely personal outlook of Clytemnestra. The heroine barely manages to escape the terrible involuntary sacrifice described as her lot in Aeschylus' Agamemnon and a virtual lynching by an enraged mob. On the other hand are the beautiful meditations on love and war, marriage and sacrifice, presented in the choral odes. Scholars have generally considered that these odes have little relation to the action or relevance to an interpretation of the play. Yet Iphigenia, as she explains and justifies her idealistic change of mind and accepts her sacrifice, appears to bridge the gap between the action and the lyrics. Is the ending, then, either ironic or a burst of pure and cleansing heroism, or both? Problems in the text compound the difficulties of interpretation since the exact contents of the prologue, exodus, and several intervening passages are dubious at best. Of necessity, then, any reading of the text remains speculative.

The structure of the Iphigenia hangs on the performance of a sacrificial ritual that is disguised for a large part of the action as a

Iphigenia hints at this possibility before her sacrifice. See Austin I968: frag. $65=$ Papyrus de la Sorbonne 2328.

${ }^{4}$ Positive readings of the $I A$ tend to celebrate Iphigenia's exercise of free will and acquisition of knowledge; ironic readings tend to emphasize the corrupt world of the play. As with many late Euripidean plays, the ambiguity is almost certainly deliberate. For a summary of older views, see the judicious discussion of Conacher I 967 a, esp. 264. Among relatively recent views, those of Garzya I 962, Snell i 968 , Strohm I957: 50-63 passim and I 37-46, and Arrowsmith (introduction to Merwin and Dimock 1978) make the strongest case for a positive reading of the sacrifice. Arrowsmith and Strohm emphasize Iphigenia's heroic exercise of free will, and Garzya her isolated moral superiority to the world of the play. Snell stresses the philosophical tone of Euripides' late plays and the movement from moral disorientation to a new idealism and determined action. Cavander I973, Dimock in Merwin and Dimock I978, and Vellacott I975 focus on the overwhelming effect of the atmosphere of uncontrolled violence and political corruption in the play. 


\section{Ritual Irony}

fictitious marriage rite. As is increasingly the case in Euripides' later tragedies, ritual and action become one; the sacrificial ritual becomes the organizing principle of the plot. Why does Euripides expand the two motifs of the sacrifice of Iphigenia and her fictitious marriage with Achilles, both mere footnotes in the previous tradition, until they dominate the play? Why does he emphasize continually the homologies between the two rites? A close examination of this neglected aspect of the text offers a useful starting point for an analysis of the complex counterpoint between the choral lyrics and the action culminating in the sacrificial death of Iphigenia. The discussion will proceed in four stages. The first section analyzes the intertwining of sacrifice and marriage in the action of the play; the second considers the treatment of these same themes in the odes. The third section examines the intersection of marriage and sacrifice in Greek society and literature to clarify the social, religious, and literary background of Iphigenia's self-sacrifice. The final section briefly considers the ritual and poetic synthesis of marriage and sacrifice in its ironic political context. As a whole the discussion shows how Iphigenia's sacrifice is first disguised as marriage, then unmasked and actually transformed into a real marriage, only to be undertaken finally as a combined marriage/self-sacrifice meant to redress Helen's perversion of her marriage to Menelaus. From this perspective, Iphigenia's sacrifice is not, as many critics have argued, a sudden, inexplicable fluke, but a well-motivated resolution of the play's social and political conflicts by way of confirmed analogies in ritual and myth between marriage and sacrifice.

\section{The Intertwining of Rituals: \\ Marriage and Sacrifice}

The ruse of marriage to Achilles that Agamemnon uses to lure Iphigenia to Aulis was known to Euripides from the epic tradition. The poet, however, may well have invented the presence of Clytemnestra and the deception of Achilles to elaborate on and complicate a traditional motif. 5 But what is even more striking in

${ }^{5}$ For a summary of treatments of the myth before Euripides, see Conacher I967a: 250-53, Schreiber I963: 66-7I, and Henrichs I98I: I98-203. 
Euripides' version is that the false marriage motif is expanded until it shares a nearly equal place with that of the sacrifice. Both the marriage and the war require a preliminary sacrifice (proteleia) to Artemis. In the early scenes of the play, while Iphigenia and Clytemnestra are still deceived as to the real purpose of Iphigenia's summons to Aulis, Euripides plays on the common details of these two rites, which have, at least superficially, a mutually exclusive aim: marriage is the happy prelude to a new life and procreation, whereas sacrifice ends in death. But by the end of the play Iphigenia against all expectation unites the two rituals. She becomes a sacrifice to Artemis and a bride, not of Hades, but of all Greece. As Cavander has suggested, "The whole play, in fact, is a grotesque wedding celebration, with the Chorus as attendants." 6 The constant repetition of ritual detail in the context of deception apparently undermines the meaning and purpose of both rites. Yet it is this very emphasis on the shared aspects of the rituals that ultimately uncovers an intrinsic harmony in the structure and purpose of marriage and sacrifice and makes possible the final transformation. In the closing scenes Iphigenia ecstatically repeats this same ritual detail in an attempt, by her acceptance of her marriage/sacrifice, to restore positive significance to Greece's political adventures and its social and religious life.

Because Clytemnestra says that she put the marriage wreath on her daughter's head (905), we know that from the moment of Iphigenia's entrance the ambiguities of her situation are plainly visible: the victim of a sacrifice, as well as a bride, is wreathed bef ore the beginning of the ritual. If the text is correct, a messenger precedes her arrival and immediately announces to Agamemnon, the leader of all the Greeks (4I4), that the "ceremony" can begin: "Begin bringing round the baskets, wreathe your head . . make ready the marriage hymn . . . let the flute play in the house and let the beat of feet in dance begin. For this day comes as blessed to the virgin" $(435-39)$. All these procedures except the joyous song and dance are common to both sacrifice and the initial rites of marriage. Linguistic factors and the heavy irony of the messenger's

${ }^{6}$ Cavander I973: I3-I4; see also 82. Schmitt I92 I: 82-83 emphasizes the intertwining of marriage and sacrifice in the first scene between Agamemnon and Iphigenia. 


\section{Ritual Irony}

request have caused commentators to excise this passage. ${ }^{7}$ Yet a transitional scene is necessary to motivate Agamemnon's decision to sacrifice Iphigenia rather than to abandon the expedition to save her, and the ironic use of ritual language is consistent with the rest of the action. The use of the otherwise later Greek verb protelizo meaning to initiate or consecrate by a ceremony, including sacrifice, preliminary to a marriage (Artemidi protelizousi tên neanida, / Aulidos anassêi, 433-34), is not merely technically precise. It also anticipates the use of the noun proteleia in later scenes and effectively recalls the repeated and ironic use of the same term in Aeschylus' Agamemnon, 8 where Iphigenia's proteleia is linked to the first deaths at Troy and to the corruption of the marriage ritual by Helen and Paris (see $A g .65,227,720$ ). Iphigenia is to become a "preliminary sacrifice." The crucial question raised in both plays is: preliminary to what other ritual or action? Yet the $I A$ expands this preliminary moment until it gains a completeness and a surprising independent significance of its own.

The messenger goes on to evoke a lyrical picture of the women waiting in a meadow just outside the camp. Iphigenia's sacrifice also occurs in a meadow sacred to Artemis (1463). In the literary tradition the image of the meadow is particularly associated with a virgin just before a rape or marriage. ${ }^{9}$ And in the archetypal case of Persephone, her rape by Hades, god of the impenetrable underworld, leads also to a form of symbolic death. The arrival of Iphigenia in a chariot may simultaneously evoke the ominous arrivals for a sacrificial death of Agamemnon and Cassandra at Argos in Aeschylus' Agamemnon, or of Clytemnestra in Euripides' own Electra; but it also suggests the image, popular in the fine arts, of the wreathed bride departing in a chariot for her husband's home, accompanied by a numphagogos (escort of the bride to the

${ }^{7}$ On the case for treating the messenger scene at $4 \mathrm{I} 4-39$ as an interpolation, see esp. England I89 I ad loc. and Page I934: I 52-54. On the other hand, most commentators agree that a scene similar to this must have occurred here for the reasons given in my text. For the importance of a scene similar if not identical to this, see esp. Cavander I973: 99.

${ }^{8}$ On the use of the term proteleia in the Agamemnon, see esp. Lebeck I97 I: Io, 48, and 68-73 and Zeitlin I965: 465-67.

${ }^{9}$ On the complex and multifaceted image of the meadow in ancient Greek literature, see Motte I973. 
groom's house, 610) and greeted on arrival by female contemporaries. ${ }^{10}$ (The word numphagogos normally describes a man, but in the unusual circumstances of this play it is used to refer to Clytemnestra. ${ }^{11)}$ In all three plays the occupants of the chariot are prepared to celebrate a festive occasion and are deceived as to the sacrificial death awaiting them. In each case they are greeted emphatically as royal, and much is made over the process of disembarkation. ${ }^{12}$ But in the $I A$ the occupants are pure of guilt, and the scene becomes a domesticated and more pitiful version of its predecessors.

In the moving first scene between Iphigenia and her father the text (despite its uncertainties) calls attention to the deceptively similar preliminaries to marriage and war by stressing the detail of the sacrifice common to both. The scene emphasizes the motif, popular in both poetry and vase paintings, of marriage as a rite of passage, a transition from a blissful girlhood presided over by loving parents to an unknown life with a man she has not met. 13 Iphigenia's playful pretense of ignorance as to the purpose for which she was brought to Troy reinforces our sense of her anxiety at the coming separation from her family; Agamemnon plays the role of a fond father suffering over the coming departure of a favorite daughter in marriage $(668-80)$ :

Iph. Shall I sail on this voyage with mother or alone?

Ag. Alone. Separated from father and mother.

Iph. You won't have me live in the homes of others, father?

Ag. Let this alone. It is not right for young girls to know such things.

${ }^{10}$ For general treatments of the procedures in Greek wedding ritual, see esp. Collignon 1904, Erdmann I 934: 250-66, Magnien I 936, Sutton I98 I, and Redfield I982. Sutton's chapter on marriage contains an up-to-date summary of the artistic evidence for Athens insofar as the vase paintings depict both men and women.

${ }^{11}$ On the use of the term numphagogos, which normally ref ers to a male but may have had a more general application, see Erdmann 1934: 257, esp. n. 91. The bride's mother of ten accompanied the marriage cart on foot on its journey to the new household.

${ }^{12}$ Textual problems make the exact nature of this greeting scene in the $I A$ uncertain.

${ }^{13}$ See van Gennep I 960 (I909); Sutton I98 I, esp. I 46-48, I 5I-52, and I 58 ; and my discussion later in this chapter. 


\section{Ritual Irony}

Iph. Hurry back from Troy to me, having put right things there, father.

Ag. First I must sacrifice a certain sacrifice here.

Iph. With holy rites [or victims] one must revere the holy.

$A g$. You will see it. For you will stand near the holy water.

Iph. Then shall we start the dances around the altar, father?

$A g$. I envy you for the ignorance I do not have. Go inside-young girls should not be seen-and give me a kiss and your hand, since you are about to live apart for so long from your father.

The ironic play on ritual continues in the dialogue immediately afterward between Clytemnestra and Agamemnon (7I 8-2I):

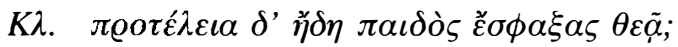

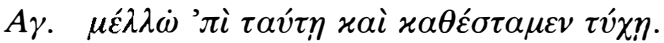

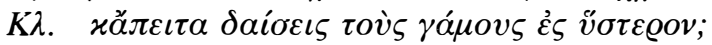

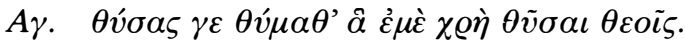

Clyt. And the proteleia, have you already sacrificed for our child to Artemis?

Ag. I am about to. We are just on the point of doing so.

Clyt. And then shall you hold the marriage feast later?

$A g$. When I have sacrificed the sacrifice I should sacrifice to the gods.

The ironic disparity between the perspectives of the two characters is underlined by the alliteration of $72 \mathrm{I}$ (also 722) and the word order of 7I8, which ominously juxtaposes paidos and esphaxas. Clytemnestra then domesticizes the scene further by insisting, almost to the point of comedy, on her role as the bride's mother. She worries about the performance of the proteleia (7I 8), the wedding banquet (722), her role as torchbearer in the ceremony (732), and the lineage of the groom (695-96). She is horrified that Agamemnon intends to deprive her of her traditional role as torchbearer (734-36) and that the wedding banquet for the women must take place by the ships (722-24).14 Agamemnon responds to this domestic tone by turning Peleus' traditional capture of his bride

${ }^{14}$ On the woman's role as torchbearer, see Sutton I98 I: 192-93, Erdmann I934: 258, and the scholiasts on Euripides' Phoenissae 344 and Troades 3 I 5. 
Thetis into a proper marriage with enguessis or engagement (Zeus ènguèse kai didōs' ho kurios, 703). Clytemnestra's daughter will marry a very well-brought-up young man (709-10).

The deception and the light tone continue briefly in the ensuing scene between Clytemnestra and Achilles. Clytemnestra at first takes her future son-in-law's negative reaction to her warm greeting as an extreme form of the aidos appropriate to a well-educated young man in the presence of women. She is deprived of her illusions about the marriage by the old man, whose loyalty to her is pointedly based on his having been a sunnumphokomos (48), a part of her dowry from Tyndareus (860). Yet she still tries to appeal to Achilles for help for herself and Iphigenia on the basis of the fictional engagement. Though the engagement was fictional-Achilles' name alone was committed-he is nevertheless compromised. As Roussel has argued, Achilles in this scene essentially accepts his role as Iphigenia's bridegroom and as the future kurios of the bride. ${ }^{15}$ In Greek marriage the enguessis, the agreement over the marriage between the groom and the father of the bride, was tantamount to marriage and a binding agreement even without the marriage ceremony. When Achilles says at 940, hagnon d'ouket' esti sōm' emon, "my body in no longer pure," he almost certainly means that the false marriage has compromised his status as an unmarried man. This point is important for two reasons. Achilles, by agreeing to act as Iphigenia's bridegroom, has complicated the sacrifice plan and undertaken a binding role in conflict with his myth, that is, with his fate at Troy. Second, the audience may be reminded here that sacrificial victims should be pure, that is, unmarried. In the Phoenissae Haimon could not be sacrificed for the city because of his engagement to Antigone (Phoen. 944-46). Roussel also invokes the "historical" example of Aristodemus (Pausanias 4.9.2-Io), whose sacrifice of a daughter is blocked by a Messenian who claims an enguessis to her. The audience might also presume, given Iphigenia's entrance as a wreathed bride, that she had already performed part of the marriage ritual, such as the dedication of her childhood toys to the gods and the farewell to the gods of her father's hearth. As the fictional marriage between Achilles and Iphigenia takes on an ever-

${ }^{15}$ Roussel I9I5, esp. $240-44$. 
increasing reality, Agamemnon's determination to sacrifice her becomes even more dubious, for Iphigenia's status as an appropriately virginal victim is by implication technically compromised along with the traditional plot.

In the second scene between husband and wife, Agamemnon continues with this fiction of the proteleia for marriage (I I I I-I3):

The lustral waters are prepared and the barley for throwing on the purifying fire and the victims, which must fall before marriage to the goddess.

With a typically Euripidean wordplay on onoma (speech) and ergon (reality), Clytemnestra challenges his fiction (II I5-I6) and ruptures the deceptive coherence between the fictional marriage and the sacrifice (I I 46-47):

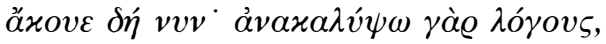

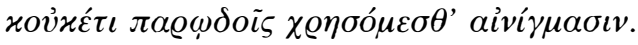

Hear me now. For I shall unveil my meaning and abandon obscure and riddling speech.

We cannot be certain of the meaning of the word paroidos, which I translate as "obscure" (LSJ gives "obscurely hinting," "singing indirectly"; England, "distorted" or "distorting"), since it is the only occurrence of the word before Aristotle. But Euripides seems here to be calling attention to the doubleness of the language used so far in the play by allowing Clytemnestra a striking word to say in effect, "You cannot use words with two referents anymore, Agamemnon." Hence this speech marks the crisis in the ritual language of the play, as the deceptive coherence between marriage and sacrifice openly breaks.

Clytemnestra now reveals that this is Agamemnon's second crime against a child of hers. Euripides invents for Clytemnestra a first marriage with Tantalus; this marriage had produced a child that Agamemnon murdered when he took the unwilling Clytemnestra, by trickery, as a bride. Until this moment Clytemnestra has nevertheless played the proper wife. Here Euripides ignores 
the hereditary curse on the family of Atreus and locates past violence pointedly in the institution of marriage. The play also stresses that Helen's betrayal of her marriage inaugurated the threat to the institution and provided a cause for a war with the barbarians; Aeschylus in the Agamemnon, in contrast, emphasizes Paris' breach of hospitality as the primary cause of the war. Agamemnon's action now renews the threat to a marriage made originally, like Helen's, under the shadow of violence. Agamemnon says that at the occasion of Helen's marriage Tyndareus used the ruse of the oath taken by the suitors to forestall temporarily a disastrous outbreak of reciprocal hostility and allowed Helen to choose a husband wherever the winds of passion swept her (IA 69); the use of wind imagery here perhaps further links Helen's marriage with Iphigenia's dilemma and the present windlessness at Aulis.

At this point in the play, then, Agamemnon's ruse is exposed, the pathetic and domestic tone of these "wedding" scenes has won much sympathy for the innocent Iphigenia, Achilles is committed to the marriage and not to the sacrifice, and the entanglement of, and identity between, the two motifs appears irresolvable. The problem is compounded in the following scene, when Achilles is seized with a genuine erōs for his bride (I 4IO-II). Iphigenia may also, as she blushingly observes Achilles for the first time and hears of his heroic willingness to sacrifice himself in her defense, be moved to act by an emerging love for the young hero. 16 Euripides' staging here perhaps reflects an increasing Athenian romanticization of wedding scenes also depicted on contemporary vase paintings, in which a youthful groom and a shy bride gaze at each other under the influence of a winged Eros. 17

In the end Iphigenia abruptly interrupts the stichomythia with a speech masterful in its formal structure and rhetoric. 18 She tran-

\footnotetext{
${ }^{16}$ For the most recent treatment of the romantic implications of this scene, see Smith I 979.

${ }^{17}$ See Sutton I 98 I, esp. I64, I77, and I 84-88.

${ }^{18}$ For a discussion of the rhetoric of Iphigenia's speech, see Schmitt I 92 I: 39-4 I, and for a summary of the interpretative controversies on this speech, see Schreiber I963, esp. 44-49. The formal structure of the speech alone helps to counter the views of critics such as Funke 1964, who see Iphigenia here as confused or as hypnotized by her father's rhetoric (on this point see also Snell I 968: 498). For a detailed criticism of Funke, see Mellert-Hoffmann i 969: 68-90, esp. 85.
} 


\section{Ritual Irony}

scends the dilemma created by the entanglement between the fictional marriage become almost real and the sacrifice needed to inaugurate the war. Echoed in detail by both the chorus and the final messenger (if the text is genuine), she welcomes each detail of the sacrificial rite as if she were indeed entering upon a marriage. At her entrance she was crowned as a bride by her mother; now, like Macaria, ${ }^{19}$ she is to be crowned as a victim (I 477-79):

Distribute wreaths. Here is my hair to crown. Bring holy water for washing.

As the voluntary sacrificial victims in Euripides often claim, Iphigenia asserts that her act will be for her paides, gamoi, and doxa (children, marriage, and reputation, I398-99). She will offer kleos (fame) to her mother as a compensation for her death (I440). Her subsequent directions, however, are atypical. She insists that the chorus dance in celebration for her (I 480-8I) in Artemis' meadow (I463), as she planned to do herself at her own proteleia for the marriage with Achilles (676). She commands her mother not to perform the traditional mourning and burial of the sacrificial victim, but to sing a paean (I 437-38, I 442, I 467-69). Paeans could be sung and/or danced on the occasions of marriages, battles, or banquets either as a gesture of thanks for an evil avoided or as propitiation of the protective deities par excellence, Artemis and Apollo. 20 The paean here seems to retain this ambiguity of occasion and function: at a marriage or at the inauguration of battle, for celebration or propitiation.

The sacrificial altar of Artemis will substitute for Iphigenia's tomb (i 444). Earlier she was doomed to be a bride of Hades (460$6 \mathrm{I}, 54 \mathrm{O}, \mathrm{I} 278)$, an image typically used of female sacrificial victims in tragedy. Now she gives her body not to Achilles or Hades, but

${ }^{19}$ For the wreathing of Macaria, see Heracleidae 529; for the sacrifice as an equivalent of children and a source of kleos, see Heracleidae 59I-92 and 534; and for Macaria's request for burial, also made by Polyxena in the Hecuba but not by Iphigenia, see 588-89. Macaria also models her act on the bravery of her father and love for her brothers. Polyxena sacrifices herself voluntarily as a gesture of freedom by one who is now a slave. The motif of the wreath and the winning of kleos are absent in her case.

20See Calame i 977: I, I47-52. 
to Greece and to Artemis (I395-97). By refusing a tomb she suggests, at least, the possibility of survival or deification. ${ }^{21}$ Iphigenia formally rejects marriage with Achilles and accepts her role as sacrificial victim in order to make the war possible and thus to save Greek marriage from the barbarian threat She will not allow Achilles to fight for her somma (body) as the Greeks will for Helen's (I4I7-20). If she is motivated by an emerging erōs, it is the controlled erōs appropriate to marriage, which the chorus celebrated earlier in the second stasimon (543-89), not the uncontrolled passion that swept Helen into a marriage first with Menelaus, then with Paris. Iphigenia acts for marriage and claims that she will receive its equivalent in recompense for her action. She departs exhorting her mother to mend her marital quarrel with Agamemnon (I454), whose action she calls involuntary (I456). Indeed, she brings to her acceptance of the sacrifice much of the form and content of her lost marriage, and her imagination has undoubtedly been stimulated and shaped by her preparations for it. The structural overlap between the two rites, so insistent throughout the plot, thus survives in the finale, with its strange mixture of violence, joyous submission, and a movement to a new existence that her mother should not mourn. 22

In the beginning Agamemnon invents a false marriage in order to accomplish an involuntary and unpropitious sacrifice of his daughter. The early scenes, by playing on the formal similarities between the two rites, emphasize his cruel deception. The middle scenes, although they expose the fiction of the marriage, ironically make this fiction so real a possibility that the entire myth of the Trojan war stands in jeopardy. Achilles is about to subvert his talents to a private rather than a public cause. He envies Greece his bride (I 406). In a final shift the false marriage becomes the basis for the resolution of the conflict and the return to the myth. In this scene, then, Iphigenia is not, as some critics have argued, merely mesmerized by fear and the rhetoric of her father into accepting

\footnotetext{
${ }^{21}$ Sesōismai in I 440 may also, as England I 89 I points out on his line I44I, ironically anticipate Iphigenia's rescue by Artemis.

${ }^{22} \mathrm{On}$ the relation between the separation of mother and daughter and that of Demeter and Persephone, see Cavander I973: 8 and I3 and my discussion later in this chapter.
} 


\section{Ritual Irony}

her self-sacrifice. ${ }^{23}$ Instead she makes the sacrifice voluntary and propitious and psychologically acceptable to herself by visualizing it as marriage. If the final scenes are genuine, she tames unbridled erōs and eris, then goes to her death untouched by hostile hands. Whereas Helen has destroyed her marriage, Iphigenia makes her act a sacrifice for marriage, a means of reconciling her parents and of restoring erōs to its proper place. The eris of the army, which was exploding in stasis (sedition) and an uncontrolled surge toward a ritual lynching, is redirected to war. As Plato claims (Rep. 47ob), war is the opposite of stasis, internal violence such as we see in later scenes of the play, where Achilles' own Myrmidons are the first to turn against him when he attempts to defend Iphigenia (I 35 I-53). In contrast, war channels internal violence outward by ritualizing and subduing it to serve an ostensibly rational cause. ${ }^{24}$ Through her extravagant merging of marriage and sacrifice, Iphigenia thus resolves the conflict between civilized feeling and private interest, which would deny her death, and political reality-the conflict between marriage, a private institution, and sacrifice, at first a private ritual for marriage but finally a proteleia to serve the interests of the community. The reason for the repeated, ironic emphasis on ritual detail in the play now becomes clear; out of ironic disparity there emerges a desperate source of salvation. The restoration of sacrifice and marriage, rituals shared by all Greeks despite their political differences, is tantamount to a symbolic restoration and definition of Panhellenic culture.

\section{The Choral Odes: The Panhellenic Perspective of Epic and Epithalamium}

The choral odes, which focus exclusively on the themes of marriage, war, and sacrifice, form a connected cycle of songs that reflect and extend in lyric form the tensions created in the ritual

${ }^{23}$ See note 18 above. For the dramatic preparation for Iphigenia's change of mind, which Aristotle found unmotivated, see Knox i 966. For an excellent discussion of the intense psychological relation between Iphigenia and her father, see Green 1979, esp. I 54, I 58, I 79, I 84.

${ }^{24}$ See Bataille I962, esp. 64 and 76; and Vernant I980: 25. 
language of the play. As in many other late Euripidean plays, the chorus is detached from the action by being composed of foreigners-in this case young Chalcidian matrons who have come to sightsee at Aulis - and the relevance of their songs to the action is oblique. At the same time their greater detachment from the action allows them to offer a more public and Panhellenic perspective on it, 25 and the separate poetic sphere that emerges in their lyrics creates a strong pressure for a return to the traditional epic version of the Trojan war. This pressure is relieved by gestures made by Iphigenia and, to a lesser degree, Achilles and (whether or not he speaks truthfully) Agamemnon. The idealistic perspective and themes presented in these odes are precisely those adopted in Iphigenia's final lyrics.

The parodos, as many scholars have observed, has a strong Homeric flavor. To the eyes of the chorus, the army of Greeks is composed of demigods or hemitheoi (I72-73). This term, almost nonexistent in Homer, looks beyond epic diction to the role of these heroes in Greek cults, and hence may serve subtly to prepare for the later claim to divine status by Iphigenia herself.26 Most of the major heroes of the Trojan war are here surveyed as they engage in orderly and beautiful activities. A catalogue of names closes with a detailed look at the brilliant Achilles, decorated with a string of epic epithets, winning a race. The ode looks backward to the causes of the war and the story of Paris and Helen, and forward by implication to Iphigenia's sacrifice, for the grove of Artemis is called poluthuton (abounding in sacrifices, I 85 ).27 Even without the disputed catalogue of ships that recalls Iliad 2.493760,28 this ode suggests the opening movements of a Trojan epic. It comes immediately after the prologue, in which Agamemnon is attempting to undo the war by preventing the sacrifice of his daughter. The epic tone of the ode creates a strong counterpressure for a return to past myth and a more glorious world than that of the stasis-ridden army and its leadership presented up to this point

${ }^{25}$ On this point see Mellert-Hoffmann I969, chap. I.

26See Nagy I 979: I 59-6 I on hèmitheoi in epic diction (Iliad I2.22-23) and in cult.

${ }^{27}$ England I 89 I cites Vitelli as the first to notice the ironic and anticipatory quality of this adjective.

${ }^{28}$ Textual problems make this section of the ode difficult to read with certainty. 


\section{Ritual Irony}

in the play. The impressionability of the blushing young women also prepares for the effect Achilles apparently has on Iphigenia, when the embarrassed and sheltered girl sees the hero for the first time. The chorus creates an expectation for a heroic Achilles, and it is important to remember that the Achilles whom Iphigenia sees is precisely the armored, larger-than-life hero of the parodos, not the more complex figure who appears in the scene with Clytemnestra.

The first stasimon $(543-89)$ comes between the scene in which Agamemnon tells Menelaus that he now must sacrifice Iphigenia, and the first meeting of Agamemnon, Iphigenia, and Clytemnestra. It deals with the nature of erōs and the roles appropriate to each sex. Immoderate erōs, like that of Helen, leads to eris. The women of the chorus yearn instead for the good erōs, that selfcontrolled, moderate love appropriate for young married women like themselves. They praise good education and aidōs (modesty). Women should hunt areta (moral excellence) in the concealed sphere of love and marriage (568-70), whereas men have infinite ways to serve their city $(570-72)$. The ode stresses the connection between marriage and war by observing the disastrous consequences of uncontrolled erotic behavior. It provides a model for correct behavior, a display of true aretē, and the aidōs and other fruits of a good education that by the end of the play are apparent to some extent in Achilles and certainly in Iphigenia. The ode shares the characters' own criticisms of their immediate situation, but it also emphasizes the motif of the marriage now abandoned by Agamemnon but still a reality for his wife and daughter, and it opens the possibility of an active pursuit of arete by a virtuous woman. Iphigenia's final action embraces and transcends this choral advice as she publically wins kleos and acts for the community (an unusual achievement for a woman, if not for the sacrificial virgins of tragedy). Yet she does so in a feminine manner, through concealed erōs (see 569) and for the cause of marriage.

The second stasimon (75I-800) follows the first scene between Agamemnon and Clytemnestra, in which Agamemnon's plan to sacrifice Iphigenia is running smoothly, and precedes the complicating appearance of Achilles, when the fictional marriage threatens to undercut the Trojan expedition. The ode again returns to the theme of Helen and her myth and offers a prophetic vision 
of the destruction of Troy and the losses to be experienced by the Trojan women. The sufferings of women bracket and undercut the achievements of war, just as the sufferings of the innocent Iphigenia threaten to undercut the expedition entirely. The rape of Leda by Zeus in disguise as a swan and the birth of Helen, recounted after the prophecy of the Trojan disaster, seem mere myths from the Muses' tablets, tales bearing no relation to painful reality (790-800, especially 797-800: en deltois Pierisin / muthoi . . . énengkan para kairon alloss). ${ }^{29}$ The ode, by questioning its own myths, questions its relevance to the world of the play's action and perpetuates the tension between odes and action. For the first time the reality of the action begins to impinge on the ideals concerning marriage and war established in the earlier odes. Yet the breadth of historical perspective offered in the ode, encompassing the past and now insistently the future, continues to reinforce a sense of the inevitability of the myth.

The famous third stasimon (I036-97) begins with the radiant marriage of Peleus and Thetis, a wedding paradigmatic in Greek tradition for its glorious ceremony, replete with the presence of the gods themselves and their divine music, songs, and gifts. ${ }^{30}$ This marriage, the centaurs arrive to predict, will produce Achilles, the most glorious warrior to fight at Troy. It also, although the chorus does not say so here, gave rise to the fatal contest of beauty among the three goddesses that led Aphrodite to promise Helen to Paris. (The connection between the beauty contest and the marriage motif is implicit in Iphigenia's lyrics at I 294-I 309, where the contest is set in a meadow where the nymphs pluck flowers.) Out of this glorious marriage (not, by most accounts, a happy one), an apparently appropriate theme for an epithalamium at the marriage of Achilles and Iphigenia, come war, strife, and the destruction of marriage through uncontrolled erōs.

29 On this kind of passage in Euripides, see Pucci 1977.

${ }^{30}$ On the third stasimon see Walsh I97I and Parry i 978: i 86ff. Neither attacks the difficult problem of the epithalamic conventions used by Euripides here. The meager surviving fragments of Greek epithalamic poetry make the latter task uncertain at best. Among later poems, Catullus 62 and Theocritus I 8 are particularly helpful. Cavander I 973: I 38-39 remarks that this stasimon could almost be read as a victory ode to Achilles. 
Very little epithalamic poetry survives from before or during the classical period. But both this fragmentary evidence and later epithalamia indicate that the ode borrows heavily from the epithalamic tradition, while the prophecy about Achilles concerns the rearming made famous in Iliad I 8. A fragment of Sappho thought to belong to an epithalamium (I4I LP) 31 includes the motif of wine-pouring at a wedding attended by the gods also present in this ode. The references to music and dance and to the promise of offspring are also epithalamic. It is impossible to say whether a prophecy of this kind was typical in songs about mythical weddings. Catullus' treatment of the wedding of Peleus and Thetis, with its prophecy by the Fates concerning Achilles (Catullus 64), may have borrowed from this ode or from a larger tradition represented also in Aeschylus (frag. 284 Mette, after Plato Rep. 383). In the Aeschylus fragment Thetis speaks bitterly of Apollo, who sang prophecies about Achilles at her wedding and then went on to-kill him at Troy. Interestingly, Catullus 64 stresses Achilles' destructiveness, whereas Euripides' ode concentrates on the visual image of the armor. Indeed, the descriptions of both the marriage and the shield have a pictorial, distant quality that contrasts with the troubled marriages and the mob violence of the action. The tone is more reminiscent of lyrics such as Sappho's fragment on the arrival of the bride Andromache at Troy (44 LP). The epithalamic themes and the hint at Achilles' future role in epic again augment the pressure for a return to an ideal and ordered social life and a Panhellenic poetic perspective on events.

The epode continues to hint at epithalamic motifs: the emphasis on the relation between the girl and her mother, the purity of the bride (here a quality of the sacrificial animal), and the comparison of the bride to a natural object (animal, plant, or flower). The chorus regrets the loss of aidōs and aretē, without which there will be no common struggle for men (koinos agōn brotois, I096), and laments Iphigenia's fate in language that densely intertwines the girl and the sacrificial victim (IO80-88):

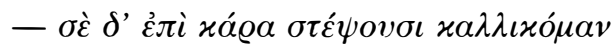 $\pi \lambda o ́ x \alpha \mu o v ' A \varrho \gamma \varepsilon \tilde{\imath} о \iota, \beta \alpha \lambda \iota \dot{\alpha} v$}

${ }^{31}$ For a discussion of this fragment, see Page i955: I24. 


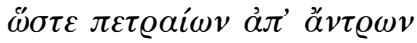 \\ $\dagger \dot{\varepsilon} \lambda \theta o \tilde{v} \sigma \alpha v$ ỏé́ $\omega v \dagger$

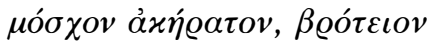

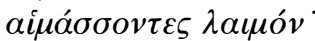

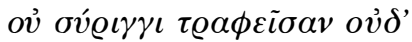

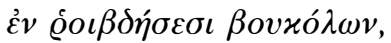

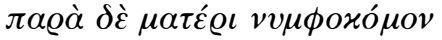

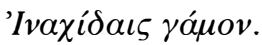

\begin{abstract}
But you - the Argives will wreathe your head with a beautiful band, like a pure, dappled heifer come from rocky mountain caves, and then bloody your human throat - a victim not raised to the tune of a pipe or the crude whistling of shepherds, but nurtured by her mother's side as a bride for the sons of Inachus.
\end{abstract}

Again, the realities of the action threaten to impinge upon the lyric ideals expressed by the chorus. At the same time, marriage and sacrifice become inextricably intertwined in a manner that anticipates the resolution of the play.

Immediately before this ode Achilles has agreed to champion Iphigenia; after it Clytemnestra and Iphigenia try to persuade Agamemnon not to sacrifice his daughter. By singing about epithalamic themes, the chorus emphasizes the multiple ironies of the situation. Achilles and the doomed Iphigenia, a sheltered girl who is in no respect an appropriate victim to pay for Helen's crimes, will never hear a wedding song. Yet the effect of the prophecy in the ode is simultaneously to deny to Achilles' intervention in favor of Iphigenia a mythical status comparable to that accorded his Iliadic wrath.

In her final scene Iphigenia's words appropriate and transform into action the promise of the odes by closing, even if illusorily, the gap between the past, with its poetic ideals for marriage and war, and the present world of the action. Her lament at I279I335, which moves from concern with family and self-pity to an awareness of her own dilemma in the larger mythical/historical context, ultimately makes more believable the final transition to public self-sacrifice. And, if the text is correct, the chorus is finally persuaded to join in this inspiring ritualized and lyric performance, perhaps even leaving an empty stage for the doubting Clytem- 
nestra. Here the wispy, distanced perspective of the odes becomes a model for the heroine's fragile idealism and offers an appropriate lyric dimension both to Iphigenia's persona and final act and to the myth and its traditional conclusion. 32 The odes, like Iphigenia's lyrics, do not deny the brutality of the events about to ensue, but their form and beauty iranslate it to another level.33 Myths and rituals thus become relevant to reality, despite the questions raised in the second stasimon concerning both myth and war's victimization of women. The very anachronism of the odes in a world in which tragedy, not epic, was the dominant art form hirits at the unworldliness of Iphigenia's transformation; and in fact Iphigenia's sacrifice is not mentioned in Homer. The further the action in the corrupt political world of the play veers from the predicted sequence of the myth, the less relevant the ideals of the odes seem to become. Yet because the distance of the chorus from the action actually makes the odes more and not less relevant to an interpretation of the play, an analysis of the play must take into account both the distance between odes and action and their crucial and climactic point of intersection.

\section{Marriage and Sacrifice}

An interpretation of İphigenia's ritual and poetic synthesis of marriage and sacrifice can be considerably enriched by an understanding of the social, religious, and literary context for these rites and the hidden structural similarities between rites upon which Euripides has built his plot. As Vernant has argued, marriage and sacrifice are homologous rites: "You could say that marriage is to sexual consummation what sacrifice is to the consumption of meat." 34 Whereas the eating of sacrificial meat ensures the physical

\footnotetext{
${ }^{32}$ Arrowsmith in Merwin and Dimock 1978: ix and xii argues that Iphigenia becomes a model of epic arete in this play.

${ }^{33}$ Bonnard I945 (anticipating Walsh I97I and Green I979) has an extensive treatment of the relation between the tragic action and the odes in this play that has influenced and complements my own. On the choral lyrics in general, see also Schreiber 1963, esp. I 5-24; Schreiber is helpful on the way in which the parodos counteracts the expectations created in the paradosis (19-20).

${ }^{34}$ Vernant I980: I $38=$ I974: I 49. Vernant's pun on consumption and consummation is impossible to translate effectively. See also Detienne 1977.
} 
continuity of existence, marriage ensures the continuity of human life over time. Marriage, sacrifice, cooked food, and the oikos stand in Greek culture in structural opposition to promiscuity, bestial allelophagy, raw food, and living in the open. The IA's literary exploitation of the homology between marriage and sacrifice has precedents in Euripides' own Alcestis (see the later discussion in this chapter) and in the mock epithalamium that Cassandra sings before her "marriage"/sacrifice with Agamemnon in the Trojan Women. 35 Segal has also argued that in Sophocles' Trachiniae marriage and sacrifice, though not precisely homologous, are simultaneously invaded by the poison of the uncivilized and erotic centaur Nessus; the closing scenes of that play, in contrast, make a parallel restoration of both institutions. ${ }^{36}$ Heracles' first sacrifice is interrupted by the workings of the poisoned robe; then he suddenly murders Lichas and bellows in unpropitious agony. But the play closes with his sacrificial death on Mount Oeta, where the rites are performed in an orderly and propitious manner. The marriage, disrupted by the intrusion of Heracles' mistress Iole into the household, is restored by Deianeira's courageous self-punishment and the marriage, however dubious, between Hyllus and Iole.

Yet the homologies between marriage and sacrifice go even deeper. Both rites involve a voluntary death, real or symbolic, designed to ensure social survival. Both seek to gain a propitious future through violence, loss and submission to a social order. Participation in a sacrifice signifies membership in a society and, by implication, submission to its rules and requirements and an entitlement to a share in its benefits. Marriage requires a comparable incorporation into the social order. The bride and groom yoke themselves in marriage for the production of legitimate children. The initial stages of each ritual mark the separation of the participants from their former state. The bride bathes and cuts her hair. The sacrificers, after washing their hands, cut off and dedicate a few hairs from the sacrificial victim and sprinkle it with water. In sacrifice the animal is made to gesture in consent to its demise; similarly, plays such as Aeschylus' Eumenides and Suppliants em-

\footnotetext{
${ }^{35}$ See Zeitlin I965 and Lebeck I97I. Aeschylus in the Agamemnon describes Cassandra's death with sacrificial imagery.

${ }^{36}$ Segal I975 and I98I.
} 


\section{Ritual Irony}

phasize the importance in marriage of peithō (persuasion) and/or Aphrodite as a necessary counterpart to bia (violence).

The Greek bride, unlike the Helen of this play (68-7I), rarely had any choice in her marriage. She was trained through ritual and other instruction from girlhood to submit to what could of ten be a frightening transitional experience. At Brauron, for example, some women of Euripides' audience (if women were present in the theater) were educated for the transition to marriage with a myth of sacrifice similar to that of Iphigenia in this play, and Iphigenia's cult was in fact intertwined with that of Artemis at Brauron. An Attic myth explained the dancing of prepubescent girls as bears in the arkteia for Artemis at Brauron as recompense for the killing of a she-bear. In one tradition Artemis demanded as an additional recompense the sacrifice of a virgin, for whom an Athenian substituted a goat dressed as a girl. As Henrichs has argued: "The Brauronian ritual commemorated the preservation and continuation of human life at the cost of animal life, and in the context of the female sex and prepuberty." 37

Other myths and texts stressed a symbolic connection between marriage and death, a connection no doubt reinforced by structural parallels between marriage and funeral rites. 38 Artemidorus argues in his Interpretation of Dreams that "marriage resembles death and is signified by death. . . . For a virgin to dream of marriage indicates her death; for all that happens to one who marries happens also to the dead" (Oneirokritika 2.65). An important Greek myth of marriage, which played a central role in the ritual life of Greek women, is the story of Persephone's rape by Hades, her stay in the underworld, and her final achievement of new divine honors and partial reunification, after experiencing sexuality, with her Olympian mother. Iphigenia's experience echoes in part that of Persephone's

${ }^{37}$ Henrichs I98I: 207. For such female initiation rituals generally, see esp. Brelich i969a and Burkert i $966 \mathrm{~b}$.

${ }^{38}$ For the marriage as death motif in ancient Greek literature, see esp. Rose 1925 and Segal I98 I: $180-83$ and 447 n. 86 on this motif in the Antigone. Redfield I 982 : I 88 and I 90 with further bibliography notes the structural parallels between marriage and funeral rites. On the importance of the Korē plot in tragedy, see Guépin I 968: 1 20-42. He makes a distinction between kathodos dramas, in which a virgin dies, and anodos dramas such as the IT or the Helen, in which the female protagonist returns from a world of death and sterility. 


\section{The Iphigenia in Aulis}

marriage/death and separation from her mother followed by the promise of new divine honors. The epithet used of Iphigenia early in the play, "the bride of Hades," was common in funerary practice and in funerary epigrams for girls who died young, and played on the analogy with Persephone. Hippolytus' experience in the Hippolytus is also modeled on the Korē myth. Like Persephone, he suffers violent separation from a sacred meadow associated with chastity. Hippolytus' rejection of Aphrodite, however, makes the necessary and violent transition to sexuality actually rather than symbolically fatal. Nevertheless, the play closes with the establishing of a cult for unmarried girls; at their marriage they will cut their hair for Hippolytus and commemorate in song Phaedra's story and Hippolytus' refusal of Aphrodite. Hippolytus will be remembered, and his and Phaedra's myth will presumably aid the young women in confronting their difficult transition to marriage. Characters from Greek tragedy such as Medea (Medea 230-5I) and the woman (Procne?) in the following fragment from Sophocles' Tereus ( $524 \mathrm{~N}=583 \mathrm{R}$ ) also frequently emphasize the violence of the transition to marriage, and make it clear why this transition could be experienced as a symbolic death:

I of ten consider how we women are nothing. When we are young, in our father's house, I think we live the sweetest life of all men; for ignorance brings us up delightfully. But when we have reached maturity and know more, we are driven out and sold, away from the gods of our fathers and our parents, some to foreigners, some to barbarians, some to strange houses, others to such as deserve reproach. And finally, after a single night has united us, we have to praise our lot and pretend that all is well.

Euripides' Alcestis and Helen capitalize on the mythical associations between marriage and death. Alcestis' promised sacrificial death for her husband $(74-76)$ recreates the primal experience of the bride. In consenting to this self-sacrifice Alcestis finally gains a second marriage, which is blessed by a proper balance of roles. Admetus wins praise for his hospitality and is no longer stigmatized by his unmasculine lack of courage to face death. The heroic Alcestis is once more a housewife, delivered veiled and silent into her husband's hands by Heracles with the traditional 


\section{Ritual Irony}

marriage gesture of cheir epi karpōi (hand on the wrist, 9i6-I7, I I 5-I9; the same gesture was used in depictions of rape and by Hermes Psychopompus). 39 Admetus' error forces him to experience a living death and a feminized housebound existence without Alcestis; indeed, it is through sharing the female's ritual experience of marriage as "death" that Admetus comes to a greater acceptance of death and a new life. The associations of this story with the Hades/Persephone myth are reinforced by the name Admetus, which is an epithet of the ever-hospitable Hades himself.

Helen and Menelaus in the Helen use the ruse of a mock funeral, which shares certain features with the Spartan marriage rite, to escape from Egypt and return finally to a propitious and real marriage, now that the fiction of Helen's voyage to Troy has been exposed. 40 Both the Odyssey, which closes with a symbolic wedding between Odysseus and Penelope (the wedding music conceals the death of the suitors), and the Helen involve a "remarriage" and a recovery of identity by a Trojan war hero, in part through his symbolic entrance into a female realm and feminine experience. Odysseus experiences both the underworld and the anonymity of the island of Calypso with its underworld associations, is reborn to the human world on Phaeacia, and goes on to rescue Penelope from an enclosed world that is unchanging and almost without growth. ${ }^{41}$ In the Helen the associations created between Egypt and Hades and the threat of a marriage with Theoclymenus enrich the complex associations between marriage and death in the play. Other treatments of the marriage and death theme involving virgins, such as Antigone's symbolic marriage af ter death with Haimon in the Antigone or Cassandra's mock epithalamium for her coming marriage/sacrifice in the Trojan Women, end ironically not in rebirth and fertility, but in sterility and death. Yet the importance of the remarriage theme in the Odyssey, the Helen, and the Alcestis provides further evidence that the marriage pattern, with its sym-

\footnotetext{
${ }^{39}$ For a discussion of the motif in art, see Sutton I98 I: 18 I and I 84 , with further bibliography, and Mylonas I 945 .

${ }^{40}$ See Plutarch Lycurgus 48. I 5.5 and Helen I087-I 620 passim. On marriage rites as an example of the transformative powers of culture, and on the woman as the acculturating partner in marriage, see Redfield I982: I85 and I 94.

${ }^{41}$ See Foley 1978 and Segal I 962.
} 
bolic death leading to birth, could offer a model for rebirth and recovery in the wake of a military or social crisis.

The action of the $I A$, insofar as it deals with the heroine, reflects not only Greek myths of marriage such as the Demeter/Persephone story, but also the pattern of separation, transition (often including a symbolic death), and incorporation characteristic, as van Gennep has shown, of initiation rites such as marriage. ${ }^{42}$ The reference to the sacred meadow, the scene of Persephone's rape, the emphasis on a journey to another place, the painful separation of parents and child, and the joyous submission, under the influence of erōs and the rhetoric of the father, to a marriage become propitious sacrifice reflect larger mythical and actual social patterns. ${ }^{43}$ Ironically, the ideal bride and the ideal sacrificial victim become one, as the education for marriage provides the mode of transition to voluntary death.

In the $I A$, however, the homology between sacrifice and marriage expands to include war, the cause for which Iphigenia is to be sacrificed. As Vernant has argued, woman functions in relation to marriage as man does in relation to war. ${ }^{44}$ Each sex, like Achilles and Iphigenia in this play, turns away from family life to accept a changed status for the benefit of the community. The woman accepts the control of a stranger to produce children, the man risks his life for the community. Each necessarily involves the kind of control or sublimation of desire emphasized in the $I A$. Indeed, Burkert has argued that the sacrifice of a virgin before battle precisely symbolizes this need to sublimate erōs for war, an erōs that is in danger of returning in a violent and uncontrolled form after battle. ${ }^{45}$ In the period of the epics, marriage is both a cause of war and a means of making alliance or reparation. As Vernant argues, "although war may end in marriage, marriage may also be at the origin of war and may cause it to spring up again." 46 This point is repeatedly emphasized in the $I A$, especially in the choral odes: Helen is the cause of the war, and Iphigenia must die to repair this

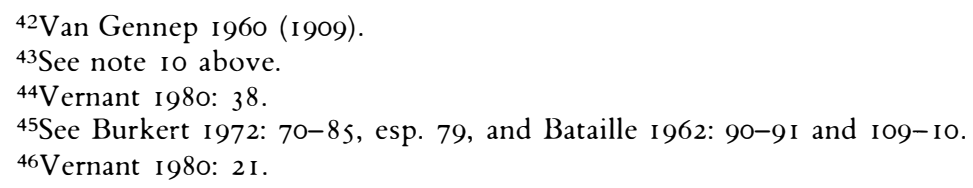




\section{Ritual Irony}

violation of marriage; marriage is the occasion for prophesying the birth of Achilles and his heroic death at Troy, and for the beauty contest that led Paris to Helen. In the Athenian polis, however, marriage had become in fact a private matter between citizens, and separate from issues of foreign policy. This contemporary situation is indirectly reflected in the strong tension between private and public, the marriage of Iphigenia and the war, found throughout the $I A$. The resolution of the play is thus an anachronistic return to myth and to the archaic reciprocity and complementarity between marriage and war, private and public, to be found in an epic or Panhellenic context.

The gesture of Iphigenia, then, not only reconnects with its myth a plot that has threatened to run out of control but also reintegrates the religious institutions of her society. Iphigenia's marriage/sacrifice is undertaken with a hint of rebirth or survival that is ratified, if the play closed this way, by Artemis' substitution of a deer for Iphigenia, a substitution that marks a propitious return to normal and civilized practice. This conclusion echoes the resolution of the earlier Iphigenia in Tauris, which closes with the transfer of a cult of Artemis from the land of the Taurians, where human sacrifice is performed in honor of the goddess, to Halae, where an animal victim will be substituted for the human. It is worth noting, before we read Iphigenia's gesture in the $I A$ as merely ironic, that all positive resolutions of Euripidean plays are achieved either through a deus ex machina or by a strategy based on ritual. In the Iphigenia in Tauris, for example, Iphigenia and Orestes use the pretense of a rite of purification for Orestes, who cannot be sacrificed to Artemis because he is a polluted murderer, to escape from the land of the Taurians and to civilize Artemis' cult. In such dramas ritual offers a possibility for salvation that is simultaneously a deception and a gesture of truth: although Iphigenia lies to Thoas about Orestes' identity and her true purpose, and Orestes has already been ritually absolved of his crime by Apollo, Orestes' voyage in the IT does finally succeed in purifying him of his matricide. 47 Both he and Iphigenia, through being willing to pity, to forgive, and to risk death for each other,

${ }^{47}$ For treatments of ritual in the $I T$, see Wolff I963, Sansone 1975 , and Strachan 1976. 
are psychologically as well as physically freed of the oppressive Trojan past. Furthermore, the resolution is achieved precisely through a realization that appearances do not offer a reliable view of the gods. In the IT Iphigenia is able, by refusing to believe that Artemis demands human sacrifice, to accept her aid and to make her ritual into a form of fiction and education. Such deception is seen as necessary to life. 48

In the Iphigenia in Aulis, rituals also offer the possibility for a deception that becomes for Iphigenia a positive psychological and symbolic reality (a sacrificial marriage), mitigated perhaps by a concluding divine rescue, and Artemis' seemingly heartless prophecy offers a script for the reunification of Greece. The achievement of a resolution through ritual implies a restoration of the social order, which is based on those rites, and a re-creation of proper contact with the gods that transcends time and place. In this and other Euripidean plays the strategy for salvation comes from a woman, a person whose imagination is shaped by poetic tradition (see the feminine view presented in the choral odes), by ritual and marriage, not by politics. In Aristophanes' Lysistrata women also simultaneously represent the interests of the private and religious worlds and of Panhellenism, external causes that transcend those of the strictly male world of the polis. ${ }^{49}$ Indeed, the contribution of women to the Greek polis was confined to the religious realm, where they were extremely active in public and private ritual. The resolution reached in such plays as the $I A$ and the Lysistrata is not a strictly political one, but involves the remaking of what Turner calls communitas, a spirit that binds together socioreligious life yet is beyond social structures; a spontaneous emotion, of ten experienced through the sacred, that makes an individual feel at one with his community, its experiences, and its memories: "Spontaneous communitas is nature in dialogue with structure, married to it as a woman is married to a man." 50 The location of communitas outside the social hierarchy of ten requires, in reality as well as in fiction, that its representative be a woman. 51

\footnotetext{
48 See Wolff I963: I 27.

${ }^{49}$ For a discussion, see Foley i $982 \mathrm{a}$.

50Turner I 969: I 40 .

${ }^{51}$ Ibid., I 84.
} 
Hence when we read as strictly ironic a plot that is resolved through ritual, we should be fully aware of the magnitude of the cynicism of such an interpretation. Such an ironic reading throws into question not only the myth and the author's interpretation of it, but the entire socioreligious system. Marriage and sacrifice, whose essential function is to unite human beings in society and to ensure social continuity, become simply instruments of deception. Certainly Euripides' treatment of the myth opens the possibility for an ironic reading of the climactic merging and restoring of marriage and sacrifice. Iphigenia dies for an army seized by an uncontrolled lust for violence. Her desire to prevent Achilles from dying for a woman (herself, I 392-93) is ironically undercut by his later death for Helen, the original corrupter of the marriage rite. 52 Clytemnestra, rejecting Iphigenia's Demeter/Persephone scenario in which the mother becomes partially reconciled to separation from her daughter, remains to the end intent on revenge and unreconciled to her marriage (see the disputed lines I455, I457, I6I6I8). The history of Clytemnestra's marriage, based on repeated violence and violation of trust by Agamemnon, undermines Iphigenia's romantic and youthful faith in her father's rhetoric, in marriage, and in Greece. On the other hand, the play opens with a disastrous and ever-widening gap between public and private, an inability in Agamemnon to accept tuche (fortune) and the demands of leadership (see especially I 6-33). Through ritual and the fictions that ritual offers for restoring the social order, Iphigenia closes this gap and accepts what tuchē brings.

\section{Ritual and the Politics of Panhellenism}

In terms of the rest of the action of the play, Iphigenia's gesture of conversion to her marriage/sacrifice is not as isolated or as unexpected as it might at first appear. All the major characters are fully implicated in the tensions raised by her dilemma, and all except Clytemnestra are drawn into participation in the sacrifice

52See Dimock in Merwin and Dimock I978: 8 . 
on Iphigenia's own terms. Like Iphigenia, all except Clytemnestra bow to a growing recognition of necessity and, however questionable their motives may be, move beyond selfish individual concerns to a fuller involvement with the community as a whole.

The myth of Iphigenia in all known versions before this play requires her sacrifice before the Greek army can go to Troy. Artemis demanded a sacrifice in one case because Agamemnon shot a sacred deer, in another in return for a promise by Agamemnon to sacrifice the most beautiful thing that the year produced, in a third case because of a hereditary curse on the Atreidae. 53 In Aeschylus' version many considerations press Agamemnon to perform Iphigenia's sacrifice: Zeus' command to avenge Paris' violation of hospitality through his abduction of Helen, a prophecy from Calchas announcing Artemis' demand for the sacrifice, the eagerness of the army, and his own desire to go to Troy. The chorus notes both his hestitation to kill his own daughter and his rapid conversion to accomplishing the act in a spirit of mad insensitivity to his own fatherhood. In the Iphigenia in Aulis Artemis offers in Calchas' prophecy not a command but a choice. The Greek army can go to Troy if Iphigenia is sacrificed; otherwise it will have to return home (89-92). In this play, then, divine forces intervene only in the form of Artemis' oracle, which offers the army a choice; in the form of the windlessness that makes the war impossible without the sacrifice; perhaps in the form of $t u c h \bar{e}$; and in the final miracle, if it occurred. The action of this play is thus unusually secularized, allowing the audience to concentrate on the moral issues raised and the choices made in response to them. Without the oracle, however, the return to ritual order and an idealized Panhellenism would have been impossible; the heartless oracle surprisingly provides a structure that allows for a transition from an atmosphere dominated by political corruption and a mindless eris to one less secularized and more oriented to public concerns.

The play opens with Agamemnon regretting his ambition and choosing the second alternative offered by the oracle. Succumbing to his love for his child, he is in the process of rewriting (meta-

53See Schreiber I963: 66-7I for the mythological sources of this passage. 


\section{Ritual Irony}

grapho, I08) the traditional script by revoking and rewriting his original letter summoning Iphigenia to Aulis. ${ }^{54}$ Euripides' plays normally begin with an iambic prologue outlining the mythological background and the situation of the character delivering the prologue. Here, if the order of the manuscript is genuine (see the appendix to this chapter), the play opens atypically with anapests followed by the expected iambic prologue giving the mythological background, and the paradosis then concludes with anapests. The unusual structure of the paradosis seems to underline in a forceful and surprising way the nature of the plot, which unfolds until the final scene as a series of attempts and failures to change the myth as it is represented in the prologue and to save the innocent Iphigenia. The metatheatrical image-Agamemnon as a writer or rewriter of myth functions for the moment as the poet's double-is in keeping with the later passages in the play that emphasize, through references to a conflict between onoma and ergon, the impossible doubleness of the language, ritual, and plot of the early scenes, in which the marriage and the sacrifice remain in unresolved conflict. 55 The unexpected intervention of the standard prologue and the seemingly awkward transition between anapests and iambics can, in my view, be explained precisely by the fact that Euripides has an artistic purpose in adopting this odd form for the paradosis and for delaying the expected iambic prologue. He wishes his audience to recognize Agamemnon's iambic speech as a Euripidean prologue; hence the speech retains the form of such a prologue, rather than being a natural reply to the old man, which would be appropriately made in anapests. 56 The delayed prologue, which outlines and then casts suspicion upon the traditional myth,

${ }^{54}$ Metagraphein means "to correct a draft or rewrite." Although it occurs only here in tragedy it is clearly the correct technical word for what Agamemnon is doing. The use of hupographo at Heracles i I 8 may be similarly metatheatrical. Here Heracles cannot believe what Amphitryon is telling him about his madness. But since the mad Heracles in fact bears little relation to the Heracles who first appears onstage in the play, two incompatible traditions confront each other in a similar fashion, because the mad Heracles is imposed on the earlier sane Heracles.

${ }^{55} \mathrm{On}$ the onoma/ergon conflict raised in the case of Achilles, who has lent his name but not his consent to the marriage, see I28, 910, 938-39. For Clytemnestra's challenge to Agamemnon on this subject, see I I 5-I6.

56The Andromeda prologue may have contained anapests, as does the prologue of the Rhesus, a play that may or may not be by Euripides. 
is then sandwiched between the unusual or unique anapests, which are reserved for the new, antimythical plot that Agamemnon is in the process of devising. In other words, Euripides is here manipulating and overturning the audience's expectations about meter and the prologue form to anticipate the contradictions in plot and language that persist throughout the play. And he does so in a manner entirely consistent with the iconoclastic manipulation of dramatic form that characterizes all his late work.

In the early scenes the characters continue to vacillate in their concern for the innocent Iphigenia; ultimately Iphigenia draws all except Clytemnestra under her sacrificial mantle and her Panhellenic idealism. Agamemnon, a former victim of gross political ambition, as Menelaus points out, is initially proud of his unheroic change of mind to pity (396-40I). He brings to bear in his argument with his brother all the hindsight of Aeschylus' chorus in the Agamemnon: the war is fought for an unworthy adulteress, and the army's eagerness for violence is sick and dangerous. Agamemnon's novel concern for his family even more surprisingly converts the formerly uxorious Menelaus. In contrast to portrayals of pairs of brothers in most other tragedies, their rivalry turns to brotherly concern and a convergence of interest. Menelaus adopts every word of his brother's position $(473-503)$ and goes on to share in his brother's next reversal. 57 Clytemnestra later persuades Achilles to abandon his destiny in Troy to protect Iphigenia, even though she is merely his bride in name. The traditionally action-loving Achilles at first hopes to be able to avoid a violent confrontation with Agamemnon and to repersuade the king, who has succumbed to fear of the Greek army and Odysseus, to save his daughter; he then shifts to active championship of his prospective bride but finally accedes to her wishes. Iphigenia, unlike other sacrificial victims in Euripides, does not immediately consent to her sacrifice. She loves life passionately. But persuaded by her father's rhetoric of Panhellenism and the inspiring presence of Achilles, who describes the state of the Greek army, she redirects the plot to the myth with her final change of mind. She rejects the offer of Achil-

\footnotetext{
${ }^{57}$ Bogaert I965 has in my view argued successfully against Parmentier I926 and Meunier I 927 that Menelaus' change of mind is meant to be genuine.
} 


\section{Ritual Irony}

les, who promises to stand by her should she change her mind once more at the altar (I424-29).

As Strohm has shown, Euripidean debates normally end in a stalemate; neither character persuades the other. 58 The tragedies in large part emerge from the clash between the passions and incompatible ideas of the characters, or from the unwillingness of a central character to change his or her mind. Changes of mind in Greek tragedy are rare outside Euripides. 59 They are usually associated with softness, the ambivalence of peitho (persuasion), femininity, and magic. In no other Euripidean play are changes of mind as pervasive as in the Iphigenia in Aulis. Particularly untragic and remarkable are the willingness to empathize with and adopt another's point of view and to give up desire (Menelaus), ambition (Agamemnon), or life so rapidly for another person.

The play offers no clear internal standards for judging these rapid shifts of mind.60 It dwells on Agamemnon's former ambition and his fear of the army, on Menelaus' self-centered desire for a wife who willingly pursued adultery, on Achilles' pomposity and egotism, and on Clytemnestra's good-willed yet narrow and bourgeois point of view. Yet all these characters, with the possible exception of Clytemnestra, are capable of positive inspiration and of undertaking considerable risks and losses to save the life of Iphigenia. They do not lose sight of what it means to kill the girl for a dubious cause. The very corruptibility and ordinariness of the

58Strohm I957: 3-49 passim.

${ }^{59}$ Knox 1966 has the most important discussion of this issue, although Schmitt I92 I: I 5-28, esp. 24-27, and Snell I968, esp. 497, contribute to the discussion. Snell emphasizes the dramatic contrast between Agamemnon's indecisiveness and Iphigenia's willingness to make a decision. Knox argues that Iphigenia's change of mind is well prepared for by the pervasive pattern of mind change in the play and motivated by the Panhellenism theme. He puts Iphigenia's change of mind into perspective by a discussion of other plays, noting the rare changes of mind in Aeschylus (the Erinyes in the Eumenides) and Sophocles (the Philoctetes) and the more frequent though more isolated changes in Euripidean drama. The rapid shifts in the $I A$ reflect the instability of the world of the play. Paradoxically, Euripides here represents a truly heroic action springing not from stubborn resolution and ideal phusis (as in Sophocles) but from a change of mind (232).

60See Snell I 968: 498-99 on the uncertainty faced by Euripidean characters in a world without definite external standards for morality. 
characters make their ability to act to a greater or lesser degree beyond their own self-interest more striking and remarkable.

The characters' openness to pity creates in the audience a desire for Iphigenia to be saved and a strong distaste for the cause to which she is to be sacrificed. At the same time, the domestic, sometimes almost comic, tone of certain scenes, like the contrast between the action and the odes, which dwell on the myth and the glories of heroic arete , evokes a sense that the move to save Iphigenia creates an alternative considerably inferior to the original myth. Iphigenia's naive urgency for her father's return home from a responsibility she does not understand (656-60) evokes strong sympathy; but her very naivété serves to emphasize further Agamemnon's failure to live up to his role as a leader. The thought that Achilles' brilliance is to be expended in protecting Iphigenia from his own army, and not on the battlefield of Troy, is at the very least discomforting.

Regardless of how the audience evaluates the motives of the characters, however, no one can in the end change the myth. The play confronts and questions the ethics of war and revenge, sets private and public concerns in conflict, and ultimately bows to the necessity of the Trojan venture; the combined force of tuche, the oracle, and the Panhellenic army is irresistible. Agamemnon, though his fear of the army and Odysseus may be despicable, is apparently justified in feeling that the arrival of Iphigenia renders her sacrifice inevitable. True, Achilles states that the army is impatient either to go to Troy or to disband (804-I 8$)$, but that is before the army learns of the prophecy. ${ }^{61}$ Menelaus, although he suggests killing Calchas (5I9), apparently bows to Agamemnon's fear of Odysseus. And it seems unlikely that the army would be vulnerable to the arguments for pity that have persuaded a brother. The army's dangerous mood is confirmed in Achilles' report of his own experience in trying to defend his bride; Achilles' heroic resistance to the facts is clearly useless. Agamemnon refers to the Aeschylean image of anangkēs zeugmata (yoke of necessity, 443) at

${ }^{61}$ Here I disagree with those such as Dimock (Merwin and Dimock I978: 9) who stress the willingness of the army to depart and thus condemn Agamemnon for his decision. For the role of tuche in the play, see esp. Ferguson I 968 and Bonnard I945. 


\section{Ritual Irony}

the moment of Iphigenia's arrival; before that, he apparently felt free to play an untraditional role. 62 According to Iphigenia, Agamemnon sacrifices his daughter akōn (unwilling) and sane (I456). The individual characters in the world of this play, though corruptible, do not fall victim so much to their own desires and hereditary madnesses as to the violence and sickness of the very Panhellenic cause (the Greek army and Greek marriage) for which Iphigenia chooses to die.

Once Iphigenia's arrival has made her sacrifice inevitable, the effort to save the girl is balanced by a gradual movement back to the myth and to the behavior associated with these characters in earlier treatments of the myth. Even the correct, well-meaning matron Clytemnestra, who remains unmoved by the Panhellenic cause, evolves into the vengeful and plotting character found in Aeschylus. The agonized father and reluctant leader mouths the rhetoric of Panhellenism, thus bringing the rhetoric of the play closer to the mood of the lyrics, and offers to his daughter at least a convincing picture of the eugeneia of his ancestors (painted as uniformly noble in this play, 29-30, 32I, 473-74, 504-5, I233, I457), which he himself lacked in earlier scenes. 63 Agamemnon, supported by Menelaus, now appears to undertake the venture to Troy as if it were a public rather than a private venture. 64 If the ending of the play is genuine, he leaves for Troy eager and unrepentant. The pompous and self-centered Achilles, who has previously been all too willing to leave the hard work to women and children and obsessively concerned with his reputation, rises, un-

${ }^{62}$ The questions of Agamemnon's vacillating character, the political pressures upon him, and the sincerity of his adoption of the rhetoric of Panhellenism have been endlessly debated. For a summary of some major views, see Conacher i $967 a$ : 261. Extensive discussions are found in Friedrich 1935, Frey 1947, Wassermann I949, Vretska i96i, Funke i964, Snell i968, and Mellert-Hoffmann i 969.

${ }^{63}$ The theme of Panhellenism is not exclusive to the odes before Agamemnon's speech. Menelaus introduces the theme into the rhetoric of the play at 370 , and, as Mellert-Hoffmann 1969 points out in chap. I, there is no reason not to take Agamemnon's statement here as a sincere expression of his views, which were temporarily overwhelmed by his private concern for his daughter.

${ }^{64}$ See Strohm 1957: 137-38. Strohm is excellent on the imprisoning effect of circumstances in the play and on the static nature of the action, which, despite counterintrigues, keeps returning to the original crisis until Iphigenia's final gesture (I37-46). 
der the influence of Iphigenia and her dilemma, to a height of inspiration and generosity that his perfect education has previously failed to instill. To Iphigenia at least he must appear a true epic knight in shining armor. Iphigenia herself fully transcends her previous naiveté and love of life in her choice to die for what appears to her to be a noble cause. But her act comes as a culmination to broader shifts in the plot, not as an isolated anomaly. This mysterious convergence of the action toward the epic promise of the lyrics (Clytemnestra excepted) and toward the traditional ending to the myth at least in part reinforces a sense of the inevitability of her sacrifice and the significance of her conversion.

The $I A$ opens with a Girardian "sacrificial crisis." The leaders of the army have been locked in a competitive struggle for power, or "mimetic rivalry": "The world of reciprocal violence is one of constant mirror effects in which the antagonists become each other's doubles and lose their individual identities." 65 Social hierarchy is collapsing; the leaders reject or are inadequate to leadership. Cultural distinctions such as those between the sexes (as when Agamemnon threatens to usurp Clytemnestra's role in the marriage ceremony) begin to be blurred. Mob violence is imminent; the army is gripped by erōs for war and revenge. In accord with the Girardian scenario, Iphigenia's sacrifice restores (and even recreates, if she is deified) the religious system and ensures social unanimity. Although the oracle left the choice for the expedition to Troy up to the Greeks, the chorus in I 402-3 finally attributes the violence of the human community exclusively to Artemis and tuche :

Your decision, young woman, is noble. But tuche and the goddess's oracle are sick.

Yet the audience cannot so easily ignore the extended experience that the play offers of the uncontrolled politics of Panhellenism and the play's repeated questioning of its own myths (see especially 72 , 790-800). Clytemnestra, if the text is genuine, finally refuses to be convinced by the messenger's proffered resolution of Iphigenia's situation (I6I5-I8):

${ }^{65}$ Girard I 978a: I 86. 


\section{Ritual Irony}

O child, you have been carried off by one of the gods? How shall I address you? How can I not call these lying tales made up [paramutheisthai tousde matēn muthous] so I will cease from bitter grief for you?

The $I A$, then, comes close to a Girardian exposure of divine violence as a mere projection of human violence upon the gods, and thus to challenging the religious system. Furthermore, the counterplot to rescue Iphigenia threatens to destroy the sacrificial system from another angle absent from earlier tragedy. It poses a politics of love against a politics of revenge. Love and pity begin to dissolve mimetic rivalry and ambition. The whole Panhellenic venture and the social hierarchy are threatened not by violence but by love, by the altruistic desire to save the innocent Iphigenia. The ultimate irony of the ending, then, is the restoration of the sacrificial system, after it has been almost exposed and rejected, when love is harnessed to imitate and serve the cause of revenge.

In the Iphigenia in Tauris, the civilizing ritual substitution of animal for human sacrifice in the cult of Artemis is accomplished through the willingness of Iphigenia, Pylades, and Orestes to forget vengeance and to sacrifice themselves through love. The cultural and religious order is finally reestablished not simply through ritual, but through a love that is also reflected in the divine sphere by the joint action of the siblings Artemis and Apollo. 66 The original sacrifice, harmlessly reenacted, becomes a model for redemption; the violence of the past, the story of Pelops as well as of Iphigenia, becomes an illusion in the light of repeated divine rescue of the victims. In the IT, ritual becomes a structure through which learning and growth beyond violence take place; the past and the present are reconnected through ritual, a ritual that must ultimately be continually reenacted (like myths in drama) as a means of recapturing the crucial memory of the original violent event. In the less optimistic $I A$, the cultural and religious order is reestablished neither by the generative violence threatened in the earlier scenes and enacted in the Bacchae, nor, as in Aeschylus, by secular justice-clearly not an alternative in Euripides' world. Iphigenia turns

66See Wolff I 963: 127 for Euripides' use of the principle of ritual substitution in the IT, Sansone 1975: 288-93 on the sacrifice of Iphigenia as a model for the redemption of Orestes, and Caldwell 1974 on psychological doubling in the play. 
the threatened lynching into an orderly and voluntary ritual (in Aeschylus the sacrifice was involuntary and hence unpropitious) through her youthful love for her father 67 and his ideals, and perhaps through an emerging love for Achilles. Ultimately, by its return to the old sacrificial system, this play finally obscures in large part the hint of an attack on the ethic of revenge and reciprocal violence in favor of voluntary sacrifice and love that Girard finds in the New Testament 68

Lack of certain knowledge about the concluding scenes makes a definitive interpretation of Iphigenia's marriage/sacrifice impossible. The text up to the point of Iphigenia's departure creates an expectation that the final scenes will confirm for Iphigenia something more than the burial accorded to her predecessors in voluntary sacrifice. Furthermore, the tradition prior to Aeschylus and to Pindar's Pythian I I also allowed for the substitution of an animal or double for the innocent girl.69 The foreshadowing of Iphigenia's rescue and survival is so strong that the disputed final scenes are hardly necessary to an interpretation of the play. In fact, the disputed extant text fulfills our expectations by placing the same emphasis on the sacrificial moment that it has up to this point. Critics of the exodus find problematic the abrupt transition from Iphigenia's departure to the messenger speech, the fragment of Aelian (De natura animalium 7.39) suggesting that Artemis herself appeared to make a speech as deus ex machina, and various other minor textual difficulties. ${ }^{70}$ On the other hand, earlier scenes do prepare us for a divine intervention, when Clytemnestra supplicates Achilles, whom she determines in desperation to treat as a god and savior (9II; in 973-74 Achilles agrees to accept the role of god). The failure of the human savior implicitly paves the way for a divine rescue.

Indeed, Euripides' plays tend to close with a series of irresolvable contradictions held in a fragile balance. The poet wrote the $I A$

67 On this point see Green I979: I79.

68See Girard I978b.

${ }^{69}$ See Henrichs I98 I: 198-203 on earlier versions of the Iphigenia myth. The Cypria and Hesiod frag. 23 allow for Iphigenia's survival.

${ }^{70} \mathrm{On}$ the problem of the exodus see, aside from the commentaries, Page I934: I 92-204 and Cecchi I960. If Artemis did appear, it is difficult to imagine how one would justify Clytemnestra's subsequent role in the myth. 


\section{Ritual Irony}

at the close of the Peloponnesian War and at a period of renewed external threats to the Greeks; some of his contemporaries were seriously offering the politics of Panhellenism as a mode of political salvation. ${ }^{71}$ Nevertheless, Iphigenia's sacrifice and the rhetoric of Panhellenism do not finally change the realities of her world. The violent Aeschylean scenario cannot be fully transformed by individual gestures of pity and self-sacrifice. And the play cannot, through the merging of marriage and self-sacrifice, achieve more than a symbolic resolution of the conflict between public and private interests that opens the play. In a sense the play brings an action dependent on the uncontrollable mob politics of injustice, found in plays such as the Orestes, into conflict with a counteraction that asserts the capacity of the individual for redemption and for learning through poetic tradition and ritual, found in the earlier Iphigenia in Tauris. The gap between the ordered and brilliant Homeric army of the parodos and the eroticized mob of the action is not closed, although Achilles finally presents himself to Iphigenia as a model of arete. The irredeemable plot, the divine demand for the sacrifice of an innocent girl for the corrupt Helen, is hardly made bearable by Iphigenia's vision and a gesture of divine pitythe substitution of a deer-and the hint of deification. Nevertheless, when politics are irredeemable, ritual and poetry offer a timeless scenario for a positive and necessary deception and for a politics of love that dissolves even while it consents to a politics of revenge. Through Panhellenic rituals and poetic forms (especially the epic and the epithalamium), Iphigenia's resolution to her dilemma bypasses, even while it is undercut by, the violent politics of the Greeks.

\section{Appendix: Lines I-I63}

I believe that the prologue of the $I A(\mathrm{I}-\mathrm{I} 63)$ has artistic merit in its present form and that the arguments against its authenticity are not sufficiently telling. ${ }^{72}$ On textual and structural points Knox's

\footnotetext{
${ }^{71}$ See Dimock in Merwin and Dimock I978: 4 on Gorgias' proposal at the Olympic games around the end of the fif th century of a Panhellenic crusade against the Persians as an alternative to intrahellenic strife.

${ }^{72}$ Older scholarship on the paradosis, such as England I89I, Page I934, 
defense remains the most forceful, but Bain's recent attack on Knox needs some discussion. ${ }^{73}$ Bain argues that Knox has not provided a convincing defense against the three most central objections made against the paradosis by previous scholars.

The first objection concerns the awkwardness of the transition from anapests to iambics. Knox defends the formal and unrealistic nature of Agamemnon's iambic reply to the old man by reference to Greek messenger speeches, which also go far beyond a narrow and naturalistic reply to the questioner. Bain objects to the analogy on the grounds that the messenger speech is designed to inform both the audience and those onstage, whereas the prologue primarily informs the audience even when other characters are present onstage. I do not find this objection compelling. The true circumstances of the situation have been kept secret from all but four members of the Greek army, and Euripides is, as often, introducing a plot that will temporarily run counter to the established myth. Hence I def end the unnaturalistic transition from anapests to iambics as a deliberate attempt to make Agamemnon's iambics seem to the audience like a delayed prologue. Even detractors of the paradosis in its present form generally admit that neither the iambics nor the anapests alone constitute an adequate introduction to the play as a whole, and the rarity of anapests in a Euripidean prologue is hard to evaluate given our limited knowledge of his corpus and the innovative nature of the dramatist.

The second objection is that lines IO5-7 and lines I 24-6 are contradictory and that consequently the anapests and iambics cannot be by the same hand. Knox defends their consistency by arguing that the statement hos echei tade ("this is the way things stand") at I06 is ambiguous: either Achilles and the army think that

Friedrich I935, and Fraenkel I955, largely concludes on the basis of difficult transitions in the text that the prologue is the work of two or more authors, one of whom may or may not be Euripides.

${ }^{73}$ The trend among recent scholars (such as Valgiglio I956, esp. I79-82, and I957; Schreiber I963; Ritchie I964; Mellert-Hoffmann I969; Willink I97I; Knox I972; and van Pottelbergh 1974) has been to defend the prologue in its present form or substantially in its present form. Willink, for example, defends the prologue but reorders it 49-96, I-48, 97-I I 4, I I 5-63. For a reply, see Bain I 977: I II4. Knox and Mellert-Hoffmann offer the most thorough defense. I here concentrate on defending Knox against Bain 1977, who off ers the only full-scale return to the views of earlier scholars. Mellert-Hoffman's views have received brief criticism in a review of her book by Diggle I97I. 


\section{Ritual Irony}

Iphigenia is coming to Aulis but do not know that the marriage is false, or Achilles and the army know nothing about the summoning of Iphigenia. The old man at I 24 interprets Agamemnon's words to mean the former, and Agamemnon then makes clear that the latter is in fact the case. Bain argues that the average spectator would not notice the initial ambiguity, and that it would be pointless for Euripides to raise such an ambiguity only to resolve it twenty lines later.

Again, Knox seems to me to take the stronger position. But it is important to note that the phrase hōs echei tade comes at the end of Agamemnon's explication of the entire situation at Aulis and almost certainly refers to the army's ignorance of more than the false marriage. As we discover later, the army and Achilles know neither about the marriage nor about Calchas' prophecy concerning the sacrifice. In fact only Agamemnon, Menelaus, Calchas, and Odysseus know anything about the situation. Iphigenia's arrival in camp will, Agamemnon immediately realizes, stimulate Odysseus to reveal Calchas' prophecy to the army and ensure Iphigenia's sacrifice. The old man's chastisement of Agamemnon at I33-35 seems to indicate that this is the first he has heard of the sacrifice. But Agamemnon's phrase, because it is so general in its application, does not exclude the possibility that Achilles knows of the marriage, but not that it is false. The old man is asking for a clarification of line ios. Euripides makes Agamemnon's phrase ambiguous because for the moment he wants to retain the possibility that Agamemnon can save Iphigenia and to make Agamemnon's sudden shift of mind to condemning his daughter dramatically plausible and surprising. But he cannot leave Achilles' situation ambiguous, since the dramatic effect of the AchillesClytemnestra scene depends on the hero's ignorance of the marriage. Hence the two passages are neither redundant or contradictory, and each prepares the audience to respond to a pivotal scene.

The final major objection is that Agamemnon has no plausible motive for reading the letter to the old man and for switching to anapests to do so. In contrast, Iphigenia in the $I T$ has a convincing motive for reading a letter. Knox conjectures that the old man will need to know the content of the letter in order to handle a delicate mission diplomatically. This is an imaginative motive, but un- 
necessary. The reason given in the $I T$ for entrusting the message to the messenger is to ensure its arrival even if the message is lost or damaged. Euripides' audience would hardly require him to quote from his earlier play, once he has there established a convention concerning letter-reading with a plausible motive (if the conventions of the Greek stage require such naturalistic motivation, which I doubt). The reading of the letter also provides Euripides with an opportunity to stress Achilles' ignorance in preparation for his later scene. But in my view the shift to anapests here serves primarily to mark a formal and clear transition to Agamemnon's antimythical plot.

Finally, it should be emphasized that Euripides' striking manipulation of dramatic form in this passage is typical of his dramaturgy as a whole. ${ }^{74}$ The chapter on the Phoenissae offers many examples. The conclusion of the Medea offers another. Here the audience expects the house doors to open to reveal the bodies of the children. Instead, Medea surprisingly appears with the children on the roof or on the machine in the chariot of the sun. The lack of so much of the Euripidean corpus makes metrical examples harder to evaluate. The use of lyrics for the messenger speech of the Phrygian slave in the Orestes underlines in a formal way the unusual nature of that speech; the slave is unable to report the exact nature of Helen's "death" to the audience and parodies Aeschylus' Cassandra (although here the enslaved Trojan cannot speak Greek). As will be seen in the chapter on the Bacchae, the use of trochaic tetrameters for Dionysus' "messenger speech" at Bacchae 6I6-4I may be another.

\footnotetext{
${ }^{74}$ For further discussion, see Arnott 1973 and Zeitlin I980. See also note 56 above.
} 